Int. J. Dev. Biol. 58: 949-959 (2014)

doi: $10.1387 / \mathrm{ijdb} .140322 \mathrm{mt}$

\title{
Integrating developmental biology and the fossil record of reptiles
}

\author{
TOMASZ SKAWIŃSKI ${ }^{1}$ and MATEUSZ TAŁANDA*,2 \\ ${ }^{1}$ Department of Evolutionary Biology and Conservation of Vertebrates, Faculty of Biological Sciences, University \\ of Wroclaw, Wroclaw, Poland and ${ }^{2}$ Department of Palaeobiology and Evolution, Faculty of Biology, Biological and \\ Chemical Research Centre, University of Warsaw, Warsaw, Poland
}

\begin{abstract}
Numerous new discoveries and new research techniques have influenced our understanding of reptile development from a palaeontological perspective. They suggest for example that transition from mineralized to leathery eggshells and from oviparity to viviparity appeared much more often in the evolution of reptiles than was previously thought. Most marine reptiles evolved from viviparous terrestrial ancestors and had probably genetic sex determination. Fossil forms often display developmental traits absent or rare among modern ones such as polydactyly, hyperphalangy, the presence of ribcage armour, reduction of head ornamentation during ontogeny, extreme modifications of vertebral count or a wide range of feather-like structures. Thus, they provide an empirical background for many morphogenetic considerations.
\end{abstract}

KEY WORDS: evo-devo, palaeontology, embryology, development, ontogeny

Introduction

Fossils are our main source of information about extinct organisms and ancestry of modern groups. Since the publication of Darwin's On the Origin of Species, people raised doubts about the utility of fossils in reconstruction of evolutionary processes (Darwin 1859). This was mainly due to the incompleteness of the fossil record. In fact, our picture of the history of life is far from being fully satisfactory. Many environments and taxonomic groups have poor preservation potential. Fossilization occurs mainly in hard, mineralized parts of the body. This is especially problematic for delicate embryos. Despite that, palaeontology and developmental biology have a long common past. As early as in nineteenth century, embryology had great influence on contemporary palaeontology. Palaeontology also influences developmental biology, because fossil record poses questions that can be tested in developmental studies (Hall 2002; Thewissen et al., 2012). However, last decades showed that fossil record is much more informative then it was previously suspected. It is especially true for reptiles, where significant advances were made (e.g. Delfino and Sánchez-Villagra 2010). Our knowledge about evolution of their development increased in recent years thanks to the remarkable findings of embryos inside female skeletons (e.g. Ji et al., 2010; Motani et al., 2014) or within mineralized eggshells (e.g. Chiappe et al., 2004; Kundrát et al., 2008; Araújo et al., 2013), sometimes even with preserved organic remains (Reisz et al., 2013), and development of new research techniques which allow us to investigate embryonic fossils which were previously inaccessible, like embryos in ovo (e.g. Balanoff et al., 2008; Fernandez et al., 2012).

It should be noted that distinguishing an embryo from the last meal might be very difficult. For example, a skeleton of a lizard preserved inside the ribcage of a theropod Compsognathus was first interpreted as an embryo of that dinosaur (see Delfino and Sánchez-Villagra 2010). Similarly, small skeletons enclosed within skeletons of adult Coelophysistheropods were sometimes regarded as embryos, subsequently assumed to be proof of cannibalism (cf. Coombs 1982) but some were recently reinterpreted as belonging to the basal crocodylomorph Hesperosuchus (Nesbitt et al., 2006; but see Gay 2010). The lack of chemical and mechanical damage (occurring in digestion), association between adult and a smaller skeleton, as well as specific anatomical traits suggest that the smaller individual is an embryo (Sánchez 2012). Sometimes, taxonomic identification of an embryo may be relatively easy, when embryo has traits almost identical to adult individuals (Kear and Zammit 2014) but in some cases even embryos may already be sexually dimorphic (Xue et al., in press), which may further hinder

Abbreviations used in this paper: EFS, external fundamental system; EPB, extant phylogenetic bracketing; GSD, genetic sex determination; TSD, temperaturedependent sex determination.

\footnotetext{
*Address correspondence to: MateuszTałanda. Żwirki i Wigury 101, 02-089 Warszawa, Poland. Tel: 00-486-9796-7540. E-mail: m.talanda@ biol.uw.edu.pl web: http://www.biol.uw.edu.pl/ewolucja
}

Accepted: 16 December 2014.

ISSN: Online 1696-3547, Print 0214-6282 
taxonomic identification. Unambiguous cases, such as fossil of a birth (e.g. Motani et al., 2014), are exceptional.

We have also to admit that most of fossil embryos represent mainly large and/or aquatic forms. This bias is due to at least three reasons: 1) organisms living in water have greater preservation potential than terrestrial ones; 2) maternal body or mineralized eggshell provide a "shelter" for embryo remains; 3 ) large animals have relatively large and better ossified embryos. Thus, most of the research concentrate on dinosaurs and marine reptiles but have interesting implications for developmental biology of all amniotes - also the recent ones (see below). Fossilized embryos, juveniles and adults can test hypotheses concerning the antiquity of developmental processes (e.g. Motani et al., 2014) and origin of morphological traits observed in living animals (e.g. Lyson et al., 2013). They also provide information about the level of homology between similar structures (e.g. Buchwitz and Voigt 2012; Godefroit et al., 2014) and answer how unique are features observed in modern taxa (Chen et al., 2014). In this review we highlight some of the recent advances in the field of developmental palaeoherpetology.

\section{Eggs}

Eggshells are more common than embryos in the fossil record. They provide useful information about embryos size and number the reproductive strategy of their parents (O'Connor et al., 2014). Moreover, they show the environment in which these embryos

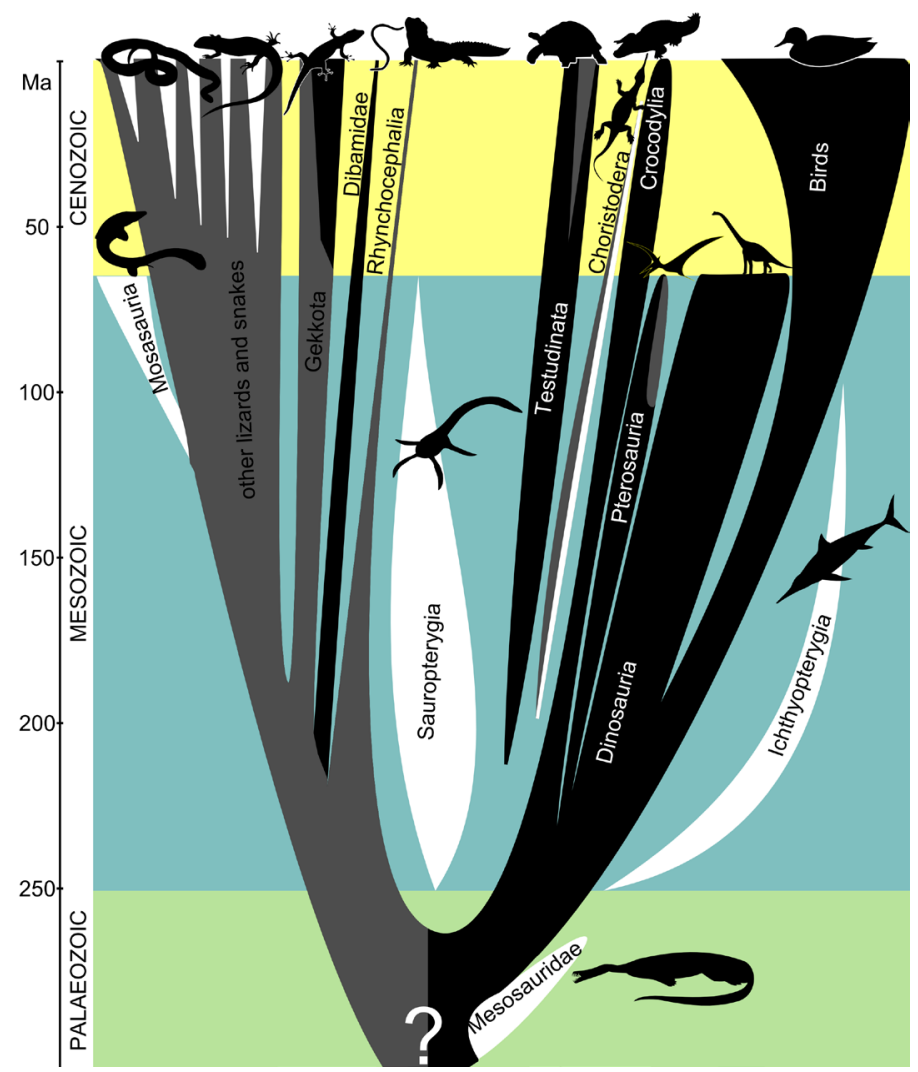

Fig. 1. A simplified reptile phylogeny showing major groups discussed in the article. Groups in black colour lay eggs with rigid, well mineralized eggshell. Grey colour denotes groups with leathery, poorly or non-mineralized eggshell. Groups in white are viviparous. Note that some clades show variation in reproductive strategies. developed (Hou et al., 2010).

The oldest known fossil eggs are much younger than the oldest known amniote fossil but, surprisingly, they are also significantly younger that the oldest known amniote embryos (Laurin et al., 2000; Piñeiro et al., 2012), despite the fact that first amniotes are generally thought to be oviparous (see Sander 2012 and discussion below). The oldest known eggs are no older than Jurassic in age (Reisz et al., 2013), whereas amniote remains are currently known from rocks no older than about 314 million years (Reisz and Müller 2004; Benton and Donoghue 2007). The most common explanation of this paradox is that first amniotes could lay small eggs with soft, poorly or non-mineralized membranes (Laurin et al., 2000). Such situation is observed in many modern and extinct groups of amniotes (e.g. Packard and DeMarco 1991; Lü et al., 2011), so it seems reasonable that it is the primitive condition.

Attempts to reconstruct the evolution of the eggshell might be difficult because of uncertain phylogenetic position of many reptile groups and very sparse early fossil record (Fig. 1). Thus, it is difficult to say, for example, when and how many times mineralized eggshell evolved. Such membrane protects the embryo, serves calcium for skeletal growth and takes part in gas and chemical changes (Grellet-Tinner et al., 2014). Well mineralized eggshell is known in birds, crocodylians, many turtles and some lizards among modern reptiles (Pike et al., 2012; Sander 2012). Most probably it is primitive for archosaurs, as it is present in both recent birds and crocodylians (Zelenitsky 2006; Marzola et al., 2015). Among archosaurs, only some pterosaurs from China (Fig. 2) are known to have non-mineralized eggshell (Unwin and Deeming 2008; Lü et al., 2011). However, findings of pterosaur eggs from South America show thin calcified shell (Chiappe et al., 2004; Grellet-Tinner et al., 2014), as well as Hamipterus eggs from China (Wang et al., 2014). Thus, condition in some Chinese forms was secondary and was probably a response to a different environmental factors and reproductive strategies. Similar variability is observed in modern gekkotans (see Grellet-Tinner et al., 2014 and references therein).

Most molecular analyses suggest that turtles are more closely related to archosaurs than to lizards (see review in Lee 2013 and references therein). This gives some credit to hypothesis that eggshells of turtles and archosaurs may have some degree of homology, despite the microstructural differences (Packard and DeMarco 1991; Hou et al., 2010). However, phylogenetic position of turtles remains controversial and does not allow us to make any definite statements. Similar situation is with the aquatic, extinct Choristodera. Like turtles, they are placed phylogenetically close to archosaurs, or lepidosaurs, or before the split of those two lineages. In contrast to most turtles, they produced leathery eggs, which makes all those considerations more complicated (Hou et al., 2010).

Dibamidae and Gekkota - two most basal squamate clades, according to molecular data (e.g. Pyron and Burbrink 2014) - are groups whose most members have well calcified eggshells (Fig. 1). Despite that, ancestral condition for Gekkota is probably a parchment-shelled egg (Pike et al., 2012). The closest relatives of lizards, rhynchocephalians, also lay soft-shelled eggs, which support the soft eggs as an ancestral lepidosaur condition (Fig. 1 ). Mineralized eggshell is probably ancestral for reptiles in general but it is yet unknown whether the leathery eggshell present in rhynchocephalians, choristoderes, most lizards and turtles is a secondary trait or a retained ancestral condition (Marzola et al., 


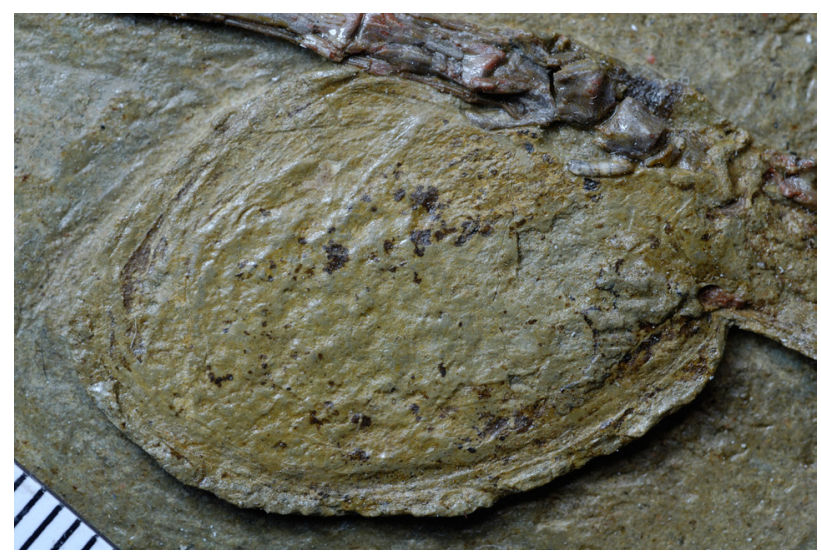

Fig. 2. A parchment-shelled egg of the pterosaur Darwinopterus (specimen ZMNH M8802). Pterosaurs are the only known archosaurs to have leathery, poorly or non-mineralized eggshell. Image courtesy of David M. Unwin.

2015; Fig. 1).

Alternatively, calcified eggs evolved multiple times independently. This is supported by microstructural differences between eggshells of squamates, archosaurs (composed mostly of calcite) and turtles (mostly aragonite) (Packard and DeMarco 1991). Variable structure of eggshell among gekkotans, pterosaurs and turtles also gives some credibility to that hypothesis.

Most of the research concerning fossil eggs is focused on dinosaurs because they had usually large eggs with rigid, well calcified shells. They exhibit great diversity of egg shapes and ornamentation. Linking each type to specific taxonomic group is still an ongoing work in palaeontology but much has already been done, especially concerning reptile-bird transition. Crocodylians have two functional oviducts and simultaneously ovulate all eggs. They produce hyper-ellipsoidal, symmetrical eggs (Zelenitsky 2006). This is probably primitive condition for all archosaurs. Advanced theropods, such as oviraptorosaurs, ovulated only one ovum per oviduct at a time. They already had asymmetrical eggs, resembling birds in this respect while retaining other primitive traits (Zelenitsky 2006). Functionality of the right oviduct was lost near the dinosaurbird transition. Smaller clutches of relatively larger eggs evolved later in birds. This sequence was tested by discoveries of nests and eggs of advanced dinosaurs and by ovarian follicles and eggs of primitive birds. The first birds laid large number of relatively small paired eggs. It could be linked to their lower metabolic rates and slower yolk deposition compared to advanced birds (O'Connor et al., 2014). They also did not move their eggs during incubation as modern forms do (Zelenitsky 2006).

Although the first reptiles were oviparous, the oldest known fossil eggs are significantly younger than the body fossils. First reptiles probably produced mineralized eggshell. Some lepidosaurs, choristoderes, pterosaurs and turtles had poorly mineralized, leathery eggshell but it is yet unknown if this is a retained primitive condition or a secondary loss. There can be some variation within a clade - for example, among pterosaurs there are known eggs with non-mineralized shell, as well as eggshells with calcareous layer, albeit very thin. Fossil eggs and their configuration within maternal body can give us important information about reproductive biology of extinct reptiles - it suggests that the functionality of the right oviduct was lost probably near the dinosaur-bird transition.

\section{Viviparity}

The egg is one of the key innovations in amniote evolution, however, in reptiles there were numerous transitions to viviparity - more than in other groups of amniotes combined. Viviparity is present in more than hundred different reptile lineages (e.g. Blackburn 2006; Pyron and Burbrink 2014), thus making reptiles an ideal group for studying the evolution of viviparity. What do fossils say on that subject?

Basically all palaeontologists agree that first reptiles were oviparous animals (Sander 2012). One of the explanations given for that hypothesis is that among extant lizards there are no known examples of transition from viviparity to oviparity (e.g. Sander 2012). However, recent phylogenetic studies on squamate reptiles suggest that parity mode is a more labile trait. Purported shifts from viviparity to oviparity are suggested at both interspecific (Surget-Groba et al., 2006) and at higher taxonomic level (Pyron and Burbrink 2014). The latter one, however, is based on the assumption that transition from viviparity to oviparity is equally probable as a converse one, which is not the case (e.g. Griffith et al., in press). Some cases of regaining oviparity from viviparous ancestors seem to be well supported (e.g. King and Lee, 2015), but they are exceptions rather than rule. Thus, there is no reason to suspect that the first reptiles were not egg-laying (Sander, 2012). Interestingly, the oldest known egg is much younger than the oldest known embryo of a live-bearing reptile (e.g. Sander 2012; see above). The early fossil record of reptile eggs and embryos is very scarce - the oldest known embryos (about 280 million years old) and the only found in Palaeozoic rocks belong to Mesosaurus tenuidens, a member of Mesosauridae, a group of basal, aquatic reptiles. Several mesosaur embryos are known - one isolated, one preserved within skeleton of adult individual and several perinatal specimens that show association with adults. Females probably carried only one or two embryos. These fossils suggests that mesosaurs were viviparous or laid eggs with well developed embryos (Piñeiro et al., 2012). These two hypotheses are not necessarily mutually exclusive, as in extant reptiles there are at least few species that have both oviparous or viviparous populations (e.g. Surget-Groba et al., 2006).

Fossil record of viviparous reptiles is much more rich in Mesozoic than in Palaeozoic but restricted mostly to marine animals. Viviparity has been described in several fossil groups: ichthyopterygians, sauropterygians, choristoderes and two lineages of lizards. Several common trends can be observed.

Viviparity probably evolved in terrestrial ancestors of aquatic groups. The embryo of an Early Triassic basal ichthyopterygian Chaohusaurus is preserved in a head-first birth posture (Fig. 3, 4) which is typical for land amniotes. In later ichthyosaurs the embryos were born tail-first (Fig. 4), which is an adaptation to fully marine lifestyle (Motani et al., 2014). Similarly, in the Late Triassic basal sauropterygian Keichousaurus, the head of an embryo is caudally oriented, as in Chaohusaurus (Cheng et al., 2004). The same is true for the Cretaceous freshwater choristodere Hyphalosaurus ( $\mathrm{Ji}$ et al., 2010). The embryos of basal mosasaur lizard Carsosaurus were first interpreted as born head-first (Caldwell and Lee 2001) but later it was suggested that such birth posture is unlikely (Motani et al., 2014). Caudal orientation of the embryo skull at birth was proposed to be a reason of high mortality during parturition, as suggested for all these forms (Caldwell and Lee 2001; Cheng et 

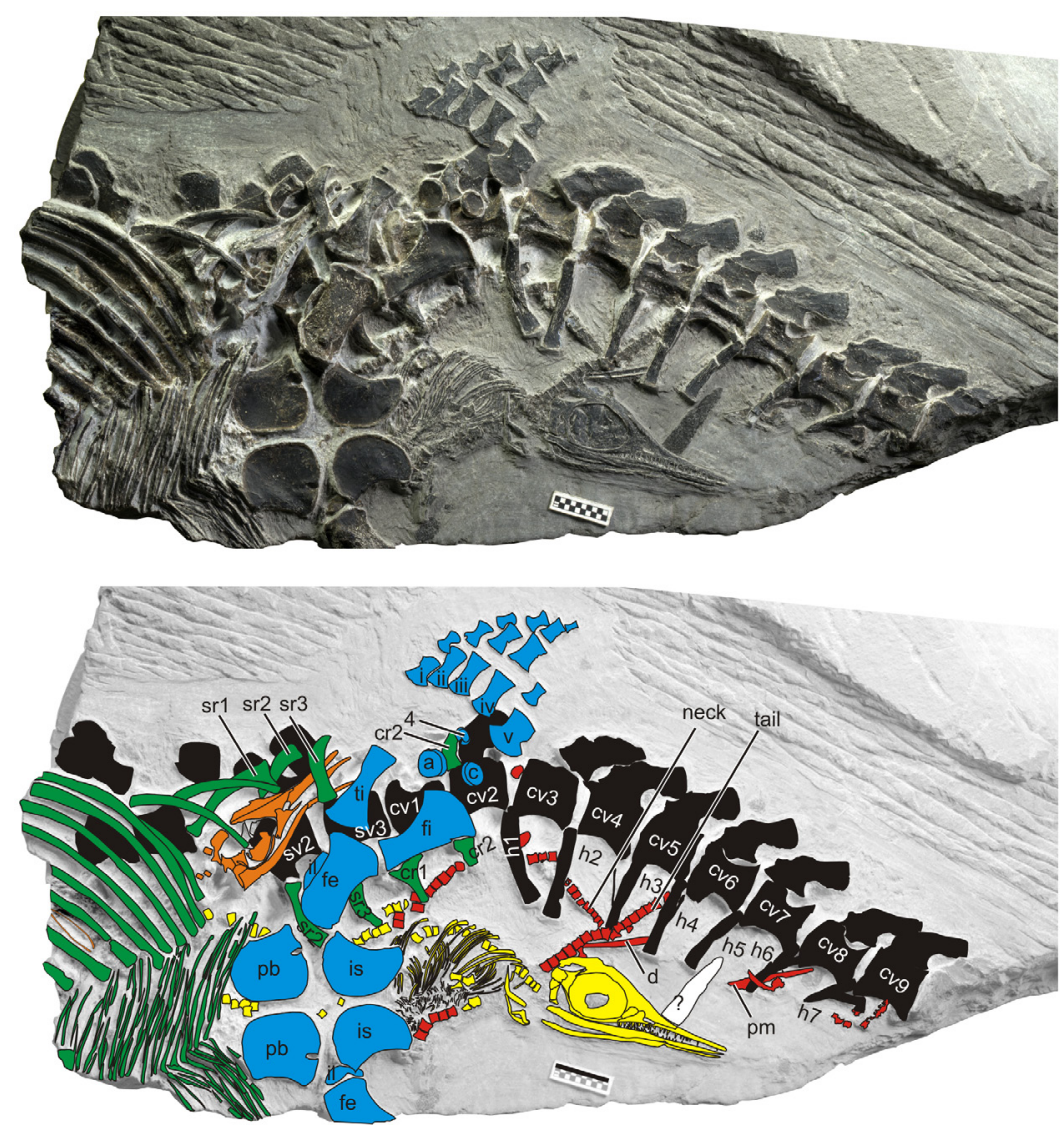

Fig. 3. Embryo of a basal ichthyopterygian Chaohusaurus preserved in a head-first birth posture, typical for land vertebrates (from Motani et al., 2014). Image available under Creative Commons Attribution 3.0 licence.

\section{al., 2004; Ji et al., 2010; Motani et al., 2014).}

Curled up embryos are known in Carsosaurus (Caldwell and Lee 2001). In one Hyphalosaurusfemale, several embryos are curled up, probably still being in their soft-shelled eggs (Hou et al., 2010), but two posterior-most embryos are straightened which is probably their birth posture (Ji et al., 2010). Also embryos of basal sauropterygians Neusticosaurus and Lariosaurusare preserved with curled vertebrae (Sander 1988; Renesto et al., 2003), in contrast to closely related Keichousaurus where there is no sign of curling of embryos (Cheng et al.,2004) which suggests different reproductive strategies among basal sauropterygians. Ichthyosaur embryos were in straight posture except early stages of development (Maxwell and Caldwell 2003).

Most fossil viviparous reptiles were giving birth to multiple progeny. If the embryos are located on both sides of the maternal body cavity, it suggests that both oviducts were functional. Such arrangement of embryos is present in ichthyopterygians (Maxwell and Caldwell 2003), Keichousaurus (Cheng et al., 2004), Hyphalosaurus (Ji et al., 2010), Carsosaurus (Caldwell and Lee 2001) and the Cretaceous terrestrial, though strongly related to aquatic habitats, lizard Yabeinosaurus (Wang and Evans 2011). An exception is the shortnecked plesiosaur Polycotylus which probably gave birth to single but relatively very large progeny (Fig. 4). In other aquatic viviparous reptiles, at the time of birth the neonates attain no more than $30 \%$ of maternal body length, while in Polycotylus it is more than $40 \%$. This suggests that in plesiosaurs a K-selected reproductive strategy evolved, i.e. giving birth to large but few progeny (O’Keefe and Chiappe 2011).

Another group of marine reptiles are metriorhynchoid crocodyliforms. There is no direct evidence of their parity mode but there are reasons to suspect that they were also viviparous. In the most derived forms, such as Cricosaurus, the deltopectoral crest on a humerus was lost, as well as pisiform in the wrist, which resulted in the changes in forelimb musculature and acted as adaptations to exclusively marine lifestyle. These characters and the reduction of limb girdle size suggest that at least some metriorhynchoids could not walk on land - for example to lay eggs. Moreover, their pelvis had increased diameter (Young et al., 2010), as in Keichousaurus, which may have been an adaptation to speeding up the birth process.

Viviparity seems to evolve almost concurrently with placentation in squamates - the clade to which all extant viviparous reptiles belong (Blackburn 2006). However, among known examples of fossil viviparous reptiles, only mosasaurs and Yabeinosaurus are squamates and sauropterygians are possibly lepidosauromorphs, while other groups are more distantly related. It is therefore unclear whether the model of evolution of viviparity in squamates can be applied to other groups. The fossil record does not give an answer to this problem because fossilized placentae are not yet known in extinct reptiles (although one example exists in the Devonian placoderm fish), even in well-preserved fossils due to the absence of relevant soft tissues (e.g. Motani et al., 2014; see a more thorough review in Blackburn and Sidor 2015).

Does the fact that in the fossil record, viviparous taxa are more abundant in water and especially marine sediments suggest that viviparity among terrestrial reptiles is - in most cases - a relatively young phenomenon, as previously suggested? (e.g. Blackburn 2006). Not necessarily, because in water there is a higher fossilization potential. The bias would therefore be taphonomic. This is also one of the reasons why fossilized amphibian ontogenies are more common in the fossil record than reptile ontogenetic series (Fröbisch et al., 2010).

Fossil evidence demonstrates that viviparity was present early in reptile evolution. Presently, all viviparous reptiles are squamates but in the Mesozoic giving birth to live young was more widespread. It was present mostly in aquatic clades such as ichthyosaurs, sauropterygians (Fig. 4) or choristoderes but at least one example of viviparous terrestrial lizard is known. This suggests a complex evolutionary history of viviparity, especially in the context of recent phylogenetic studies which suggest numerous transitions from oviparity to viviparity (and vice versa?) in squamates.

\section{Sex determination}

Sex determination is a crucial phenomenon in population biology and ecology and -in consequence-evolution. In reptiles, sex determination mechanisms are much more diverse than in other groups of amniotes - birds and mammals, where sex is determined only genetically. Except genetic (GSD), reptiles exhibit also temperaturedependent sex determination (TSD), where temperature during embryogenesis decides about the sex of an embryo. However, one should note that there is no solid barrier between GSD and TSD; 
even in species with sex chromosomes, temperature may play some role in determining the sex of an embryo (e.g. Janes 2010). TSD and GSD should rather be seen as two ends of a continuum (e.g. Sarre et al., 2004). Neither TSD, nor GSD are homogenous categories - in both of them, there are at least few major subtypes (such as homo- and heteromorphic sex chromosomes, three types of TSD; e.g. Janes 2010).

Despite the fact that sex-determining mechanisms do not fossilize, sex determination in fossil reptiles receive much attention. In extant reptiles, temperature-dependentsex determination occurs in all major lineages - squamates, turtles, crocodylians and sphenodontians; in the latter two, it is the only sex-determining mechanism (e.g. Janzen and Krenz 2004). Temperature-dependent sex determination probably appeared very early in reptile evolution and may be an ancestral trait for turtles, sphenodontians, crocodylians (Janzen and Krenz 2004) and the clade Archosauromorpha, which contains crocodylians and all reptiles more closely related to them than to lizards, i.e. archosaurs, theirclose extinct relatives and possibly turtles (Organ and Janes 2008). Quite commonly, there is intrafamilial or even intrageneric variation in sex-determining mechanism, which suggests that evolutionary transitions between GSD and TSD are relatively easy (Sarre et al., 2004) but there are different possible explanations of that phenomenon - Janes et al., (2010) point to the role of mutations, while Quinn et al., (2011) suggest the effect of sex gene dosage and changes in thermosensitivity within population.

It has been suggested that sex determination in fossil taxa is impossible to infer (Rage 1998) but currently, based on anatomy and biology of extinct organisms, comparisons to related recent taxa and sophisticated statistical methods it is possible to infer probability of a given sex-determining mechanism in a given fossil taxon. Especially sex-determining mechanisms in non-avian dinosaurs attracted a lot of attention. Some authors suggested that dinosaurs exhibited TSD which led to their extinction at the end of the Cretaceous (e.g. Miller et al., 2004). Extant Phylogenetic Bracketing does not give an answer to this problem because birds and crocodylians - the closest extant relatives of non-avian dinosaurs - have different types of sex-determining mechanisms (e.g. Silber et al., 2011). However, discovery of neosauropod nesting site at hydrothermal environment, where dinosaurs nested repetitively (Grellet-Tinner and Fiorelli2010), suggests that TSD is unlikely in these animals.
Only three of all recent viviparous reptiles have TSD - all of them are skinks (Robert and Thompson 2010). Viviparity was also common in fossil reptiles (see above), especially in marine reptiles such as ichthyosaurs, sauropterygians and mosasaurs (Fig. 4). All recent fully pelagic, viviparous amniotes (i.e. sea snakes, sirenians and cetaceans) exhibit GSD so it seems probable that pelagic, viviparous fossil reptiles also had GSD. Organ et al., (2009) discovered a correlated evolutionary change between genetic sex determination and viviparity in modern reptiles using a reversible-jump Markovchain Monte Carlo algorithm to find a Bayesian posterior probability distribution of models of correlated change. The analysis strongly suggests that ichthyosaurs, sauropterygians and mosasaurs acquired GSD prior to the evolution of live birth (Fig. 4). Sex-determining mechanisms seem to be impossible to infer in fossil oviparous taxa, while in viviparous reptiles, a null hypothesis should probably be assuming that they had genetic sex determination (Organ et al., 2009; Janes 2010).

Sex-determining mechanisms do not fossilize but they can be inferred even in some fossil reptiles, mostly based on data from living taxa. Statistical tests suggest that genetic sex determination predates origin of viviparity in a given lineage, which means that marine viviparous reptiles such as ichthyosaurs, sauropterygians and mosasaurs probably had genetic sex determination. Temperaturedependent sex determination probably appeared early in reptile evolution and may be ancestral for sphenodontians, turtles and archosauromorphs. Numerous transitions between TSD and GSD are known. Fossil evidence may also give clues about sex determination type of extinct reptiles. For example, repetitive nesting of some sauropod dinosaurs at hydrothermal site seems to argue against TSD in these animals.

\section{Fossils, genes and development}

Genes that underlie different developmental mechanisms do not fossilize. However, that does not mean that we cannot infer the degree of expression of a given gene based on fossilized phenotype and using an extant phylogenetic bracketing. Even fossils of adults can be informative, especially when there is an unambiguous correspondence between given phenotype and given developmental process (Sánchez 2012).

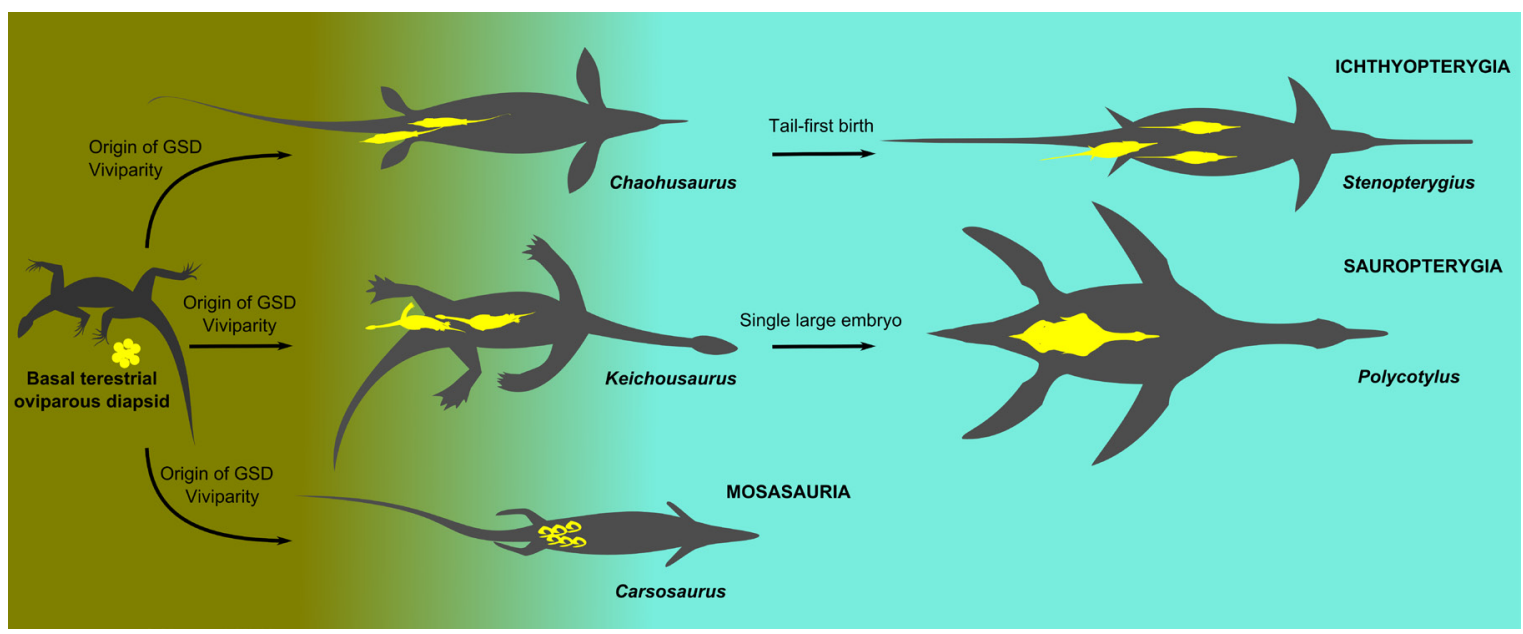

Fig. 4. Evolution of sex determination and parity mode in major groups of marine reptiles. It seems that genetic sex determination evolved prior to viviparity in those clades (see text for details). 
Historically, morphology of the temporal region of the skull played an important role in reptile systematics. On the basis of a number and location of additional skull openings (fenestrae), reptiles were divided into several groups - anapsids, diapsids, synapsids and euryapsids. In turtles, which have anapsid skull (i.e. with no fenestrae) - during embryonic growth Runx2 and Msx2 genes are expressed in mesenchymal cells in the temporal region, what results in complete temporal roofing (Tokita et al., 2013). It is possible that in other reptiles with anapsid skulls, like armoured pareiasaurs or procolophonids (all extinct), such pattern was present. However, this is far from certain due to the unstable position of turtles on the phylogenetic tree. Traditionally, turtles were considered to be the most basal living reptiles, while most molecular studies suggest that they are archosauromorphs which lost their temporal openings. It does not preclude the close relationship between turtles and other anapsids (Lee 2013). If those two groups are closely related, their similar morphologies suggest that their genes were also similar.

The turtle shell is a unique structure among amniotes. Given the uncertain phylogenetic position of turtles (e.g. Lee 2013), the evolutionary origin of this structure is contentious. However, evolutionary developmental studies shed some light on this subject. The shell is composed of dorsal part - the carapace - and ventral one - the plastron. Plastron is present in all known turtles, while the carapace is absent in the earliest known turtle, the Late Triassic Odontochelys. The carapacial ridge is a crucial structure in the development of the carapace; it is a longitudinal ridge in the flank, present only in turtle embryos. This suggests that in embryos of the earliest turtles like Odontochelys, the carapacial ridge formed only temporarily and incompletely. More advanced turtles, including early forms like the Late Triassic Proganochelys, probably had complete carapacial ridge (Kuratani et al., 2011). Eunotosaurus, a Late Permian putative close relative of turtles, had no shell so probably also had no carapacial ridge. However, its ribs were broadened in a similar way to those of the turtles, probably as a result of outgrowing (sub)dermal bone from perichondrium (Lyson et al., 2013). Some other reptiles also had broadened, plate-like ribs with limited movability, e.g. basal sauropterygians Sinosaurosphargis and Henodus. It was suggested that these taxa and turtles are closely related and all inherited genetic basis for carapace development. Similarly to turtles, ribs of Sinosaurosphargis are not derived from exoskeletal components (Hirasawa et al., 2013). However, the phylogenetic position of both sauropterygians and turtles is highly unstable (e.g. Lee 2013), rendering the hypothesis of deep homology uncertain. Moreover, the armours of turtles and basal sauropterygians differ in their microanatomies, as shown by histological analyses (Scheyer et al., 2013).

Another notable trait of the sauropterygians is their variability in vertebral numbers. Vertebrate body axis consists of many repeated units - the vertebrae. Their development is driven by somitogenesis and Hoxgene expression, so the morphology of the adult vertebrae can tell us about somitogenesis and rate of segmentation during embryonic growth. While mammals are highly conserved in the number of precaudal vertebrae, reptiles are very diverse in this respect. Reconstruction of ancestral vertebral counts suggests that first reptiles had six cervical and twenty one dorsal vertebrae. Several general trends in the evolution of vertebral counts can be observed: marine reptiles tend to have many more vertebrae than terrestrial (with some long-necked plesiosaurs having more than 70 cervical vertebrae) and armoured clades, such as pareiasaurs, turtles or ankylosaurs, have relatively small vertebral counts. This gives us information on the rate of segmentation which is lower in some clades but much higher in others, like snakes which can have more than 300 precaudal vertebrae (Müller et al., 2010). The increase in number of vertebrae in snakes was followed by reduction of regional differentiation, i.e. expansion of thoracic identity in axial skeleton, which occurred probably very early in snake evolution (Cohn and Tickle 1999; Zaher et al., 2009). However, a recent morphometric study suggests that the snake skeleton did not lose its regionalization, but rather retained an ancestral amniote pattern of Hox gene expression (Head and Polly, 2015) - with relatively minor modifications (see Guerreiro and Duboule, 2015 and references therein) - which is supported by morphology of early reptiles such as Palaeozoic Captorhinus. High regionalization of skeletons of birds (and, to a lesser extent, crocodylians) and mammals - compared to snakes - seems to be acquired independently (Head and Polly, 2015). One of the most basal known snakes, Najash, still had sacrum - loss of sacral region must have then occurred in more advanced snakes. None of the known snakes, both extant and extinct, has forelimbs, which means that complete loss of their specification took place very early. However, well developed hindlimbs are known in some fossil snakes such as Najash, Dinilysia, Eupodophis, Pachyrhachis, Pachyophis or madtsoiids (e.g. Zaher etal., 2009). These developmental changes are supposed to be followed by transformation of the entire axial skeleton towards thorax and finally to elimination of hindlimb specification in alethinophidians except booids and pythonoids (Cohn and Tickle 1999). However, phylogenetic position of the limbed taxa listed above is contentious - some of them may be nested within crown snakes (Zaher et al., 2009), thus suggesting more complex pattern of evolution of developmental processes.

Even though birds are just a species-rich reptile lineage, traditionally they are not considered reptiles and they are not treated in this review. However, one of the traits historically considered to be unique to birds - feathers - could evolved in their non-avian ancestors. Feather-like structures have been discovered in many dinosaurs and even in pterosaurs, the probable sister group of dinosauromorphs, thus raising possibility that all those taxa were ancestrally feathered ( $\mathrm{Xu}$ and Guo 2009). One specimen is of particular interest because it shows that both feathers and scales may be present on one individual. Kulindadromeus, a basal ornithischian dinosaur (a group that did not give rise to birds), had feather-like integuments around the head, thorax and proximal limbs and scales around the tail and distal hindlimbs. Especially the scales on the distal hindlimbs are interesting because of their similarity to scales on the birds' legs. In birds, these scales develop through inhibition of feather development, regulated by sonic hedgehog pathway. It is possible that similar process occurred in Kulindadromeus (Godefroit et al., 2014). Elongated integuments are also known in the Triassic reptile Longisquama and some authors considered them to be very important in the evolution of feathers, despite highly uncertain phylogenetic position of that taxon among diapsid reptiles (e.g. Dzik et al., 2010; Buchwitz and Voigt 2012). Development of these structures is quite similar to that of avian feathers, for example in differentiation along the proximo-distal axis. This suggests some degree of homology between those appendages. While there is no phenotypic evidence of feather-like integuments outside of Ornithodira, genes that control development of such structures might have been present much earlier, 
possibly in the last common ancestor of Longisquama and birds (Buchwitz and Voigt 2012). This hypothesis is partly supported by finding that majority of feather regulatory elements originated before dinosaurs and were probably present in first archosaurs (Lowe et al., 2015). The deep homology (i.e. homology of genes but not their phenotypic effects) has been hypothesized to play role also in the evolution of dinosaur integuments (Godefroit et al., 2014). Studying morphogenesis of skin integuments of other reptiles may shed more light on that subject.

Another supposedly avian trait that appeared before the origin of birds is the digit configuration of the avian wing. Basal theropods had five digits in the manus, with the digits 4 and 5 strongly reduced. Birds and many advanced theropods have only three digits (e.g. Bever et al., 2011 and references therein). Embryological studies showed that bird digits develop from digital positions 2-3-4. This conflict has been used as an argument against the dinosaurian origin of birds (e.g. Burke and Feduccia 1997). Wagner and Gauthier (1999) proposed a hypothesis explaining these differences, the "frame-shift hypothesis": it assumes that mesenchymal condensations that used to develop as digits 2-3-4, at some point of theropod evolution started to develop in positions of digits 1-2-3 (Wagner and Gauthier 1999). Although some experimental studies argue against this frame-shift (Towers et al., 2011), most of them support this hypothesis (e.g. Tamura et al., 2011; Salinas-Saavedra et al., 2014). Currently, most authors tend to pose questions "how?" and "when?" rather than "whether?" the frame-shift occurred (e.g. Bever et al., 2011; Young et al., 2011; Seki et al., 2012). The fossil record seemed to unambiguously suggest that advanced theropods (including birds) have digits 1-2-3 but that hypothesis was challenged by the discovery of a four-fingered basal ceratosaur Limusaurus with strongly reduced digit 1 , which was interpreted as supporting a 2-3-4 hypothesis. The authors suggest that Limusaurus shows the intermediate stage of the frame-shift which was completed in more advanced theropods - the tetanurans (Xu et al., 2009). However, this scenario has been questioned and the strong reduction of digit 1 was interpreted as a derived trait of the ceratosaurs, thus having nothing to do with the avian condition (Seki et al., 2012). Moreover, recent embryological studies support digit identities in birds (and thus other advanced theropods) as 1-2-3 (e.g. Tamura et al., 2011; Towers et al., 2011; Salinas-Saavedra et al., 2014). Discovery of more fossils of basal ceratosaurs and basal tetanurans would certainly help understand the digit homologies and time of the frame-shift in theropod evolution. Regardless of that, it seems that homeosis played an important role in the evolution of the theropod forelimb; it was proposed that also the "semilunate" carpal in the wrist of most theropods (including birds) underwent a homeotic transformation during evolution, as suggested by the positional shift of that structure (Xu et al., 2014).

While reduction of some digits is a relatively common phenomenon among recent and fossil reptiles (e.g. theropods), the opposite trends - hyperphalangy and polydactyly - are very rare among extant amniotes but present in some fossil reptiles. It is difficult to reconstruct developmental processes based on osteology alone but some hypotheses can be put forward. For example, polydactyly in ichthyosaurs is supposed to evolve from fixed different expression of Shh or Ihh genes and isolated expression of HoxA11-13 genes. Absence of fifth digit in mosasaur lizards may be result of prolonged expression of HoxD in the absence of HoxA. Modifications of time of gene expression or gene dosage effect might be the causes of hyperphalangy (Caldwell 2002).

Clear correlations between a given developmental process and given phenotype allow us to reconstruct some aspects of development of fossil reptiles. It is especially interesting in groups with bizarre morphology. For example, highly modified anatomy of turtles seems to be a result of several changes during their development. These include expression of Runx2and Msx2 in mesenchymal cells in the temporal region which results in closed skull and the origin of carapacial ridge which is crucial for the development of the carapace. It is yet unclear whether or to what extent we can extrapolate these processes on extinct reptiles with similar traits - anapsids and some sauropterygians. Data from fossils give us information about developmental plasticity of extinct reptiles, as exemplified by their high variation in vertebral numbers. Fossils suggest that limblessness, and thus developmental processes responsible for loss of limb specification, evolved several times within snake lineage. Homeosis probably played an important role in the evolution of the theropod forelimb - currently, most (but not all) authors agree that the frame-shift occurred and advanced theropods (including birds) have digits 1-2-3. The opposite phenomenon, increasing the number of digits, is very rare but was present in some extinct marine reptiles such as ichthyosaurs. While all modern reptiles have typical scaly skin, many extinct ones exhibited wide range of integumentary structures on their bodies. Homology between some of these integuments, like those of Longisquama, and others, such as bird feathers, is yet uncertain. Probably only future fossil discoveries can clarify their relations.

\section{Indeterminate vs. determinate growth, age assessment and taxonomy}

Age assessment is a crucial problem in developmental palaeobiology. It can give us important information about growth of the animal and processes responsible for its development. Ontogenetic data can also have serious implications for taxonomy.

It is commonly assumed that reptiles exhibit an indeterminate growth, i.e. they grow until death (see review in Congdon etal., 2013). Fossil evidence show that this view is problematic and erroneous in many cases at least. Whether an animal grows indeterminately, can be checked through osteohistological analysis. Determinate growth is assumed when in the outermost bone cortex occurs an external fundamental system (ESF) - a bone microstructure which indicates cessation of bone growth. External fundamental system has been found in long bones of some individuals of not only highly derived modern alligators (Woodward et al., 2011) and some Triassic crocodylian-line archosaurs which metabolism was higher than in recent crocodylians (Ricqlès et al., 2003) but also in dyrosaurid crocodyliforms (Andrade and Sayão 2014), pterosaurs (Steel 2008), rhynchosaurs (Veiga et al., in press), and even some lepidosaurs (Hugi and Sánchez-Villagra 2012), among others. This suggests that determinate growth is primitive for diapsids and may be "a rule rather than exception" (Woodward et al., 2011). However, even in recent literature there are suggestions that indeterminate growth could play an important role in attaining large size by many dinosaurs (Delfino and Sánchez-Villagra 2010) but EFS is known in many dinosaur taxa (e.g. Curry 1999; Padian etal., 2004), including sauropods such as Apatosaurus which was about $25 \mathrm{~m}$ in length (Curry 1999). Moreover, absence of an EFS does not necessarily imply indeterminate growth, it suggests rather that individual in 
A

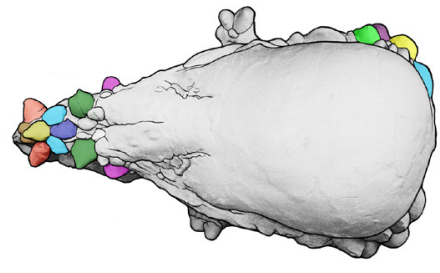

C

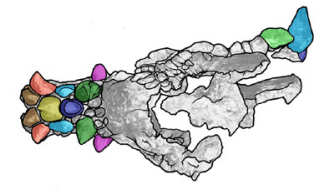

E

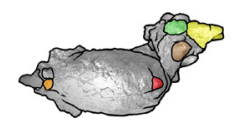

G

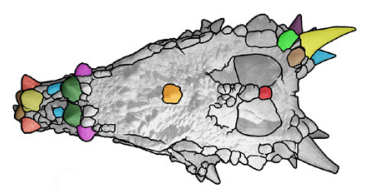

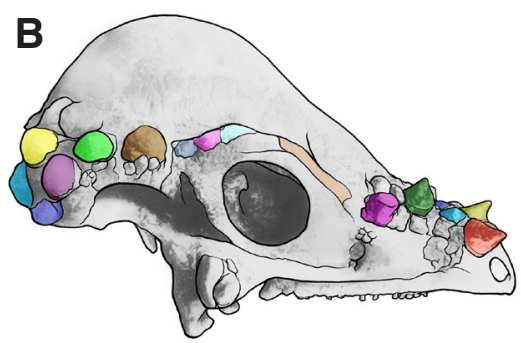

D

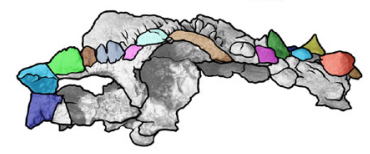

$\mathbf{F}$

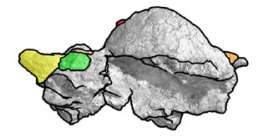

H

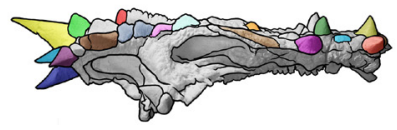

Fig. 5. Hypothesized cranial ontogeny of Pachycephalosaurus, showing inflation of the skull dome but also reduction of cranial ornamentation. The oldest individual is shown in $\mathbf{( A , B )}$ while $\mathbf{( G , H )}$ are the youngest, originally described as Dracorex. $(\mathbf{C}, \mathbf{D})$ were originally described as Stygimoloch. Scale bar, $5 \mathrm{~cm}$ (from Horner and Goodwin 2009). Image available under Creative Commons Attribution 2.5 licence.

question died before reaching maximum size (e.g. Woodward et al., 2011). This may be due to the high mortality and/or habitat differences - as a result, only some animals attain skeletal maturity (Myhrvold 2013). While EFS is usually not present in all specimens of a given taxon - sometimes in none of them (Myhrvold 2013) - its widespread presence on a phylogenetic tree supports hypothesis about early origin of capability to stop growing. In some cases, EFS is present in relatively small animals while absent in bigger ones (e.g. Woodward et al., 2011) - this means that it is impossible to assess skeletal maturity based on size alone. Timing of suture closing is also problematic (e.g. Irmis 2007), meaning that it can be achieved only by histological analysis. This may have serious implications for taxonomy. Numerous pterosaur mandibular symphyses of different sizes from the Upper Cretaceous of Hungary were thought to represent a growth series of an azhdarchid Bakonydraco galaczi. However, the smallest histologically studied individual turned out to be an adult, not juvenile, as expected. This, combined with microanatomical differences between that specimen and other adult pterosaurs in the sample, suggests that at least two distinct species are present in that assemblage (Prondvai et al., 2014).

Histological analyses can be a reason not only of splitting but also lumping taxa together. For example, Dracorex, Stygimoloch and Pachycephalosaurus were regarded as three distinct taxa of pachycephalosaurid dinosaurs but cranial osteohistology combined

with morphology and computer tomography suggest that two former taxa are only growth stages of the latter (Fig. 5). This is interesting because Dracorex and Stygimoloch had more pronounced skull ornamentation than Pachycephalosaurus (Fig. 5). This ontogenetic series would therefore be a rare example of reducing cranial ornamentation during ontogeny (Horner and Goodwin 2009). Another case for integrating developmental data in taxonomy is the debate about potential synonymy of the ceratopsian dinosaurs Torosaurus and Triceratops ("synonymy through ontogeny"), where the former may be mature form of the latter, as suggested by morphology and osteohistology (e.g. Scannella and Horner 2010). However, this case seems to be more controversial than in Pachycephalosaurus (e.g. Maiorino et al., 2013).

Bone histology is an important technique in studying ontogeny of fossil animals. It may contribute to challenging some of the traditional concepts such as indeterminate growth in reptiles - in at least several clades of reptiles, both extant and extinct, an external fundamental system has been found which indicates cessation of growth. Osteohistological analyses may have serious implications for taxonomy, for example by showing that animals regarded as different taxa were in fact only ontogenetic stages of the same taxon (or conversely). Sometimes ontogenetic series recognized this way show rare phenomena, such as reduction of cranial ornamentation during ontogeny, as observed in pachycephalosaurs.

\section{Conclusions}

New remarkable findings and methodological advances give us new perspective on the evolution of development in reptiles. However, developmental biology of the earliest reptiles remains enigmatic. Reptile body fossils are known from the Carboniferous but the oldest known embryos come from the Permian while the oldest known eggs are from the Jurassic. This huge gap in the fossil record makes it very difficult to conclusively reconstruct ancestral reptilian condition. This is further hindered by uncertain phylogenetic placement of some major clades.

Viviparity has been demonstrated in several lineages of fossil reptiles, mostly aquatic ones. It seems that transition to viviparity preceded colonization of fully marine habitats, as suggested by caudal orientation of embryos within maternal body cavity of an early ichthyopterygian. Most of the viviparous fossil reptiles gave birth to multiple progeny but an example of K-selected reproductive strategy has been found among short-necked plesiosaurs. Strong correlations between evolution of genetic sex determination and viviparity suggests that sex of extinct marine reptiles was determined genetically. Some aspects of developmental genetics can be inferred in fossil animals, especially when there is a clear correspondence between developmental process and a specific phenotype.

Studying late ontogeny of some fossil reptiles brought other unexpected discoveries. Bone histological studies of fossil reptiles show that many of them were capable of ultimately cease growing, as indicated by presence of an external fundamental system. EFS 
has been discovered in bones of most major reptile groups which suggests that determinate growth may be ancestral for reptiles. It is thus possible that determinate growth will be discovered in greater number of extant reptiles. Major morphological changes have been discovered in late ontogeny of dinosaurs like pachycephalosaurs, where reduction of cranial ornamentation has been postulated $-\mathrm{a}$ very rare phenomenon among extant animals.

Many discoveries in reptile developmental biology would be impossible without incorporating palaeontological data and taking an interdisciplinary approach. It is important to study fossil taxa because they give us information about the origin of traits present in modern animals and developmental processes that underlie them. Moreover, they often exhibit morphologies that are significantly different from those of modern animals and document phenomena that are rare or even completely absent among extant organisms.

\section{Acknowledgements}

We thank Małgorzata Kloc (Houston Methodist Hospital), Jacek Kubiak (University of Rennes) and two anonymous referees for helpful comments on the manuscript. We thank David M. Unwin (University of Leicester) for his kind permission to reproduce an image of Darwinopterus egg.

\section{References}

ANDRADE R CLP de and SAYÃO J M (2014). Paleohistology and lifestyle inferences of a dyrosaurid (Archosauria: Crocodylomorpha) from Paraíba Basin (northeastern Brazil). PLoS One 9: e102189.

ARAÚJO R, CASTANHINHA R, MARTINS R M S, MATEUS O, HENDRICKX C BECKMANN F, SCHELL N and ALVES L C (2013). Filling the gaps of dinosaur eggshell phylogeny: Late Jurassic theropod clutch with embryos from Portugal. Sci Rep 3: 1924.

BALANOFF A M, NORELL M A, GRELLET-TINNER G and LEWIN M R (2008). Digital preparation of a probable neoceratopsian preserved within an egg, with comments on microstructural anatomy of ornithischian eggshells. Naturwissenschaften 95: 493-500.

BENTON M J and DONOGHUE P C J (2007). Paleontological evidence to date the tree of life. Mol Biol Evol 24: 26-53.

BEVER G S, GAUTHIER J A and WAGNER G P (2011). Finding the frame shift: digit loss, developmental variability, and the origin of the avian hand. Evol Dev 13: 269-279.

BLACKBURN D G (2006). Squamate reptiles as model organisms for the evolution of viviparity. Herpetol Monogr 20: 131-146.

BLACKBURN D G and SIDOR C A (2014). Evolution of viviparous reproduction in Paleozoic and Mesozoic reptiles. Int J Dev Biol. 58: XXX-XXX

BUCHWITZ M and VOIGT S (2012). The dorsal appendages of the Triassic reptile Longisquama insignis: reconsideration of a controversial integument type. Paläontol Z 86: 313-331.

BURKE A C and FEDUCCIAA (1997). Developmental patterns and the identification of homologies in the avian hand. Science 278: 666-668.

CALDWELL M W (2002). From fins to limbs to fins: limb evolution in fossil marine reptiles. Am J Med Genet 112: 236-249.

CALDWELL M W and LEE M S Y (2001). Live birth in marine Cretaceous lizards (mosasauroids). Proc R Soc Lond B Biol Sci 268: 2397-2401.

CHEN X, MOTANI R, CHENG L, JIANG D and RIEPPEL O (2014). A carapace-like bony 'body tube' in an Early Triassic marine reptile and the onset of marine tetrapod predation. PLoS One 9: e94396.

CHENG Y, WU X and JI Q (2004). Triassic marine reptiles gave birth to live young. Nature 432: 383-386.

CHIAPPE L M, CODORNIÚ L S, GRELLET-TINNER G and RIVAROLA D D (2004). Argentinian unhatched pterosaur fossil. Nature 432: 571-572.

COHN M J and TICKLE C (1999). Developmental basis of limblessness and axial patterning in snakes. Nature 399: 474-479.

CONGDON J D, WHITFIELD GIBBONS J, BROOKS R J, ROLLINSON $\mathrm{N}$ and
TSALIAGOS R N (2013). Indeterminate growth in long-lived freshwater turtles as a component of individual fitness. Evol Ecol 27: 445-459.

COOMBS W P, Jr (1982). Juvenile specimens of the ornithischian dinosaur Psittacosaurus. Palaeontology 25: 89-107.

CURRY KR (1999). Ontogenetic histology of Apatosaurus (Dinosauria: Sauropoda): new insights on growth rates and longevity. J Vertebr Paleontol 19: 654-665.

DARWIN C (1859). The Origin of Species by Means of Natural Selection. John Murray, London.

DELFINO M and SÁNCHEZ-VILLAGRA M (2010). A survey of the rock record of reptilian ontogeny. Semin Cell Dev Biol 21: 432-440.

DZIK J, SULEJ T and NIEDŻWIEDZKI G (2010). Possible link connecting reptilian scales with avian feathers from the early Late Jurassic of Kazakstan. Hist Biol 22: 394-402.

FERNANDEZ V, BUFFETAUT E, MAIRE E, ADRIEN J, SUTEETHORN V and TAFFOREAU P (2012). Phase contrast synchrotron microtomography: improving noninvasive investigations of fossil embryos in ovo. Microsc Microanal 18: 179-185.

FRÖBISCH N, OLORI J C, SCHOCH R R and WITZMANN F (2010). Amphibian development in the fossil record. Semin Cell Dev Biol 21: 424-431.

GAY R J (2010). Evidence related to the cannibalism hypothesis in Coelophysis bauri from Ghost Ranch, New Mexico. In Notes on Early Mesozoic Theropods. Lulu Press, pp. 9-24.

GODEFROIT P, SINITSA S M, DHOUAILLY D, BOLOTSKY Y L, SIZOV A V, MCNAMARA M E, BENTON M J and SPAGNA P (2014). A Jurassic ornithischian dinosaur from Siberia with both feathers and scales. Science 345: 451-455.

GRELLET-TINNER G and FIORELLI L E (2010). A new Argentinean nesting site showing neosauropod dinosaur reproduction in a Cretaceous hydrothermal environment. Nat Commun 1: 32.

GRELLET-TINNERG, THOMPSONMB, FIORELLILE, ARGAÑARAZE, CODORNIÚ L and HECHENLEITNER LM (2014). The first pterosaur 3-D egg: implications for Pterodaustro guinazui nesting strategies, an Albian filter feeder pterosaur from central Argentina. Geosci Front 5: 759-765.

GRIFFITH O W, BLACKBURN D G, BRANDLEY M C, VAN DYKE J U, WHITTINGTON C M and THOMPSON M B (in press). Ancestral state reconstruction require biological evidence to test evolutionary hypotheses: A case study examining the evolution of reproductive mode in squamate reptiles. J Exp Zool B Mol Dev Evol DOI: 10.1002/jez.b.22614

GUERREIRO I and DUBOULE D (2014). Snakes: hatching of a model system for Evo-Devo? Int J Dev Biol. DOI: 10.1387/ijdb.150026dd

HALL B K (2002). Palaeontology and evolutionary developmental biology: a science of the nineteenth and twenty-first centuries. Palaeontology 45: 647-669.

HEAD J J and POLLY P D (2015). Evolution of the snake body form reveals homoplasy in amniote Hox gene function. Nature 520: 86-89.

HIRASAWA T, NAGASHIMA H and KURATANI S (2013). The endoskeletal origin of the turtle carapace. Nat Commun 4:2107.

HORNER J R and GOODWIN M B (2009). Extreme cranial ontogeny in the Upper Cretaceous dinosaur Pachycephalosaurus. PLoS One 4: e7626.

HOU L, LI P, KSEPKA D T, GAO K and NORELL M A (2010). Implications of a flexible-shelled eggs in a Cretaceous choristoderan reptile. Proc $R$ Soc Lond $B$ Biol Sci 277: 1235-1239.

HUGI J, SÁNCHEZ-VILLAGRA M R (2012). Life history and skeletal adaptations in the Galapagos marine iguana (Amblyrhynchus cristatus) as reconstructed with bone histological data-a comparative study of iguanines. J Herpetol46:312-324.

IRMIS R B (2007). Axial skeleton ontogeny in the Parasuchia (Archosauria: Pseudosuchia) and its implications for ontogenetic determination in archosaurs. $J$ Vertebr Paleontol 27: 350-361.

JANES D E (2010). Extinct and extant reptiles: a model system for the study of sex chromosome evolution. In Evolutionary Biology - Concepts, Molecular and Morphological Evolution (Ed. P Pontarotti). Springer, Berlin-Heidelberg, pp. 3-17.

JANES D E, ORGAN C L and EDWARDS S V (2010). Variability in sex-determining mechanisms influences genome complexity in Reptilia. Cytogenet Genome Res 127: 242-248.

JANZEN F J and KRENZ J G (2004). Phylogenetics: which was first, TSD or GSD? In Temperature-Dependent Sex Determination in Vertebrates (Eds N Valenzuela and V.A Lance). Smithsonian Institution Press, Washington, pp. 121-130.

JI Q, WU X and CHENG Y (2010). Cretaceous choristoderan reptiles gave birth to 
live young. Naturwissenschaften 97: 423-428.

KEAR B J and ZAMMIT M (2014). In utero foetal remains of the Cretaceous ichthyosaurian Platypterygius: ontogenetic implications for character state efficacy. Geol Mag 151: 71-86.

KING B and LEE M S Y (2015). Ancestral state reconstruction, rate heterogeneity, and the evolution of reptile viviparity. Syst Biol 64: 532-544.

KUNDRÁT M, CRUICKSHANKAR I, MANNING T W and NUDDS J (2008). Embryos of therizinosauroid theropods from the Upper Cretaceous of China: diagnosis and analysis of ossification patterns. Acta Zool 89: 231-251.

KURATANI S, KURAKU S and NAGASHIMA H (2011). Evolutionary developmental perspective for the origin of turtles: the folding theory for the shell based on the developmental nature of the carapacial ridge. Evol Dev 13: 1-14.

LAURIN M, REISZ R R and GIRONDOT M (2000). Caecilian viviparity and amniote origins: a reply to Wilkinson and Nussbaum. J Nat Hist 34: 311-315.

LEE M S Y (2013). Turtle origins: insights from phylogenetic retrofitting and molecular scaffolds. J Evol Biol 26: 2729-2738.

LOWE C B, CLARKE J A, BAKER A J, HAUSSLER D and EDWARDS S V (2015). Feather development genes and associated regulatory innovation predate the origin of Dinosauria. Mol Biol Evol 32: 23-28.

LÜ J, UNWIN D M, DEEMING D C, JIN X, LIU J and JI Q (2011). An egg-adult association, gender, and reproduction in pterosaurs. Science 331: 321-324.

LYSON T R, BEVER G S, SCHEYER T S, HSIANG A Y and GAUTHIER J A (2013). Evolutionary origin of the turtle shell. Curr Biol 23: 1113-1119.

MAIORINO L, FARKE A A, KOTSAKIS T and PIRAS P (2013). Is Torosaurus Triceratops? Geometric morphometric evidence of Late Maastrichtian ceratopsid dinosaurs. PLoS One 8: e81608.

MARZOLA M, RUSSO J and MATEUS O (2015). Identification and comparison of modern and fossil crocodilian eggs and eggshell structures. Hist Biol27: 115-133.

MAXWELL E E and CALDWELL M W (2003). First record of live birth in Cretaceous ichthyosaurs: closing an 80 million years gap. Proc $R$ Soc Lond B Biol Sci 270: S104-S107.

MILLER D, SUMMERS J and SILBER S (2004). Environmental versus genetic sex determination: a possible factor in dinosaur extinction? Fertil Steril 81: 954-964.

MOTANI R, JIANG D, TINTORI A, RIEPPEL O and CHEN G (2014). Terrestrial origin of viviparity in Mesozoic marine reptiles indicated by Early Triassic embryonic fossils. PLoS One 9: e88640.

MÜLLER J, SCHEYER T M, HEAD J J, BARRETT P M, WERNEBURG I, ERICSON P G P, POL D and SÁNCHEZ-VILLAGRA M R (2010). Homeotic effects, somitogenesis and the evolution of vertebral numbers in recent and fossil amniotes. Proc Natl Acad Sci USA 107: 2118-2123.

MYHRVOLD N (2013). Revisiting the estimation of dinosaur growth rates. PLoS One 8: e81917.

NESBITT S J, TURNER A H, ERICKSON G M and NORELL M A (2006). Prey choice and cannibalistic bahaviour in the theropod Coelophysis. Biol Lett 2: 611-614.

ORGAN C L and JANES D E (2008). Evolution of sex chromosomes in Sauropsida. Integr Comp Biol 48: 512-519.

ORGAN C L, JANES D E, MEADE A and PAGEL M (2009). Genotypic sex determination enabled adaptive radiations of extinct marine reptiles. Nature 461: 389-392.

O'CONNOR J K, ZHENG X, WANG X, WANG Y and ZHOU Z (2014). Ovarian follicles shed new light on dinosaur reproduction during the transition towards birds. Natl Sci Rev 1: 15-17.

O'KEEFE F R and CHIAPPE L M (2011). Viviparity and K-selected life history in a Mesozoic marine plesiosaur (Reptilia, Sauropterygia). Science 333: 870-873.

PACKARD M J and DEMARCO V G (1991). Eggshell structure and formation in eggs of oviparous reptiles. In Egg Incubation. Its Effects on Embryonic Development in Birds and Reptiles(Eds D.C Deeming and M.W.J Ferguson). Cambridge University Press, Cambridge, pp. 53-70.

PADIAN K, HORNER J R and RICQLÈS A J de (2004). Growth in small dinosaurs and pterosaurs: the evolution of archosaurian growth rates. J Vertebr Paleontol 24: 555-571.

PIKE D A, ANDREWS R M and DU W-G (2012). Eggshell morphology and gekkotan life-history evolution. Evol Ecol 26: 847-861.

PIÑEIRO G, FERIGOLO J, MENEGHEL M and LAURIN M (2012). The oldest known amniotic embryos suggest viviparity in mesosaurs. Hist Biol 24: 620-630.
PRONDVAIE, BODORER and ŐSIA(2014). Does morphology reflect osteohistologybased ontogeny? A case study of Late Cretaceous pterosaur jaw symphyses from Hungary reveals hidden taxonomic diversity. Paleobiology 40: 288-321.

PYRON R A and BURBRINK F T (2014). Early origin of viviparity and multiple reversions to oviparity in squamate reptiles. Ecol Lett 17: 13-21.

QUINN A E, SARRE S D, EZAZ T, MARSHALL GRAVES J A and GEORGES A (2011). Evolutionary transitions between mechanisms of sex determination in vertebrates. Biol Lett 7: 443-448.

RAGE J C (1998). Latest Cretaceous extinctions and environmental sex determination in reptiles. Bull Soc Geol France 169: 479-483.

REISZ R R and MÜLLER J (2004). Molecular timescales and the fossil record: a paleontological perspective. Trends Genet 20: 237-241.

REISZ R R, HUANG T D, ROBERTS E M, PENG S, SULLIVAN C, STEIN K, LEBLANC A R H, SHIEH D, CHANG R, CHIANG C, YANG C and ZHONG S (2013). Embryology of Early Jurassic dinosaur from China with evidence of preserved organic remains. Nature 496: 210-214.

RENESTO S, LOMBARDO C, TINTORI A and DANINI G (2003). Nothosaurid embryos from the Middle Triassic of northern Italy: an insight into the viviparity of nothosaurs? J Vertebr Paleontol 23: 957-960.

RICQLÈS A J de, PADIAN K and HORNER J R (2003). On the bone histology of some Triassic pseudosuchian archosaurs and related taxa. Ann Paléontol 89: 67-101.

ROBERT K A and THOMPSON M B (2010). Viviparity and temperature-dependent sex determination. Sex Dev 4: 119-128.

SALINAS-SAAVEDRAM, GONZALEZ-CABRERAC, OSSA-FUENTESL, BOTELHO J F, RUIZ-FLORES M and VARGAS A O (2014). New developmental evidence supports a homeotic frameshift of digit identity in the evolution of the bird wing Front Zool 11: 33

SANDER P M (1988). A fossil reptile embryo from the Middle Triassic of the Alps Science 239: 780-783.

SANDER P M (2012). Reproduction in early amniotes. Science 337: 806-808.

SARRE S D, GEORGES A and QUINN A (2004). The ends of a continuum: genetic and temperature-dependent sex determination in reptiles. Bioessays 26:639-645.

SÁNCHEZ M (2012). Embryos in Deep Time. University of California Press, Berkeley, Los Angeles, London.

SCANNELLA J B and HORNER J R (2010). Torosaurus Marsh, 1891 is Triceratops Marsh, 1889 (Ceratopsidae: Chasmosaurinae): synonymy through ontogeny. $J$ Vertebr Paleontol 30: 1157-1168.

SCHEYER T, WERNEBURG I, MITGUTSCH C, DELFINO M and SÁNCHEZ-VILLAGRA M (2013). Three ways to tackle the turtle: integrating fossils, comparative embryology, and microanatomy. In Morphology and Evolution of Turtles (Eds D.B Brinkman, P.A Holroyd and J.D Gardner). Springer, Dordrecht, pp. 63-70.

SEKI R, KAMIYAMA N, TADAKORO A, NOMURA N, TSUIHIJI T, MANABE M and TAMURA K (2012). Evolutionary and developmental aspects of avian-specific traits in limb skeletal pattern. Zoolog Sci 29: 631-644.

SILBER S, GEISLER J H and BOLORTSETSEG M (2011). Unexpected resilience of species with temperature-dependent sex determination at the Cretaceous-Palaeogene boundary. Biol Lett 7: 295-298.

STEEL L (2008). The palaeohistology of pterosaur bone: an overview. Zitteliana 28B: $109-125$.

SURGET-GROBAY, HEULIN B, GUILLAME C-P, PUKY M, SEMENOVD, ORLOVA V, KUPRIYANOVAL, GHIRA I and SMAJDAB (2006). Multiple origins of viviparity, or reversal to oviparity? The European common lizard (Zootoca vivipara, Lacertidae) and the evolution of parity. Biol J Linn Soc 87: 1-11.

TAMURA K, NOMURA N, SEKI R, YONEI-TAMURA S and YOKOYAMA H (2011). Embryological evidence identifies wing digits in birds as digits 1, 2, and 3. Science 331: 753-757.

THEWISSEN J G M, COOPER L N and BEHRINGER R B (2012). Developmenta biology enriches paleontology. J Vertebr Paleontol 32: 1223-1234.

TOKITA M, CHAEYCHOMSRI W and SIRUNTAWINETI J (2013). Skeletal gene expression in the temporal region of the reptilian embryos: implications for the evolution of reptilian skull morphology. SpringerPlus 2: 336.

TOWERS M, SIGNOLET J, SHERMAN A, SANG H and TICKLE C (2011). Insights into bird wing evolution and digit specification from polarizing region fate maps. Nat Commun 2: 426. 
UNWIN D M and DEEMING D C (2008). Pterosaur eggshell structure and its implication for pterosaur reproductive biology. Zitteliana B28: 199-207.

VEIGAF H, SOARES M B and SAYÃO J M (in press). Osteohistology of hyperodapedontine rhynchosaurs from the Upper Triassic of Southern Brazil. Acta Palaeontol Pol. DOI: 10.4202/app.00074.2014

WAGNER G P and GAUTHIER JA(1999). 1,2,3 =2,3,4: A solution to the problem of the homology of the digits in the avian hand. Proc Natl Acad Sci USA 96: 5111-5116.

WANG Y and EVANS S E (2011). A gravid lizard from the Cretaceous of China and the early history of reptile viviparity. Naturwissenschaften 98: 739-743.

WANG X, KELLNER A W A, JIANG S, WANG Q, MA Y, PAIDOULA Y, CHENG X, RODRIGUES T, MENG X, ZHANG J, LI N and ZHOU Z (2014). Sexually dimorphic tridimensionally preserved pterosaurs and their eggs from China. Curr Biol 24: 1323-1330.

WOODWARD H N, HORNER J H and FARLOW J O (2011). Osteohistological evidence for determinate growth in the American alligator. $J$ Herpetol 45: 339-342.

XU X and GUO Y (2009). The origin and early evolution of feathers: insights from recent paleontological and neontological data. Vertebrata PalAsiatica 47:311-329.

XU X, CLARK J M, MO J, CHOINIERE J, FORSTER C A, ERICKSON G M, HONE D W E, SULLIVAN C, EBERTH D A, NESBITT S, ZHAO Q, HERNANDEZ R, JIA C,
HAN F and GUO Y (2009). A Jurassic ceratosaur from China helps clarify avian digital homologies. Nature 459: 940-944.

XU X, HAN F and ZHAO Q (2014). Homologies and homeotic transformation of the theropod 'semilunate' carpal. Sci Rep 4: 6042.

XUE Y, JIANG D, MOTANIR, RIEPPELO, SUNY, SUN Z, JI C and YANG P (in press). New information on sexual dimorphism and allometric growth in Keichousaurus hui, a pachypleurosaur from the Middle Triassic of Guizhou, South China. Acta Palaeontol Pol. DOI: 10.4202/app.00006.2013

YOUNG M T, BRUSATTE S L, RUTA M and ANDRADE M B de (2010). The evolution of Metriorhynchoidea (Mesoeucrocodylia:Thalattosuchia): an integrated approach using geometric morphometrics, analysis of disparity, and biomechanics. Zool J Linn Soc 158: 801-859.

YOUNG R L, BEVER G S, WANG $Z$ and WAGNER G P (2011). Identity of the avian wing digits: problems resolved and unsolved. Dev Dyn 240: 1042-1053.

ZAHER H, APESTEGUÍAS and SCANFERLA C A (2009). The anatomy of the Upper Cretaceous snake Najash rionegrina Apesteguía \& Zaher, 2006, and the evolution of limblessness in snakes. Zool J Linn Soc 156: 801-826.

ZELENITSKY D K (2006). Reproductive traits of non-avian theropods. J Paleontol Soc Korea 22: 209-216. 


\section{Further Related Reading, published previously in the Int. J. Dev. Biol.}

Sexual dimorphism of AMH, DMRT1 and RSPO1 localization in the developing gonads of six anuran species

Rafal P. Piprek, Anna Pecio, Katarzyna Laskowska-Kaszub,Jacek Z. Kubiak and Jacek M. Szymura

Int. J. Dev. Biol. (2013) 57: 891-895

Dual embryonic origin of the hyobranchial apparatus in the Mexican axolotl (Ambystoma mexicanum)

Asya Davidian and Yegor Malashichev

Int. J. Dev. Biol. (2013) 57: 821-828

Clonal analyses in the anterior pre-placodal region: implications for the early lineage bias of placodal progenitors

Sujata Bhattacharyya and Marianne E. Bronner

Int. J. Dev. Biol. (2013) 57: 753-757

Amphibian interorder nuclear transfer embryos reveal conserved embryonic gene transcription, but deficient DNA replication or chromosome segregation

Patrick Narbonne and John B. Gurdon

Int. J. Dev. Biol. (2012) 56: 975-986

Origins of $\mathrm{Cdx} 1$ regulatory elements suggest roles in vertebrate evolution

Stephen J. Gaunt and Yu-Lee Paul

Int. J. Dev. Biol. (2011) 55: 93-98

Reptile scale paradigm: Evo-Devo, pattern formation and regeneration

Cheng Chang, Ping Wu, Ruth E. Baker, Philip K. Maini, Lorenzo Alibardi and Cheng-Ming Chuong

Int. J. Dev. Biol. (2009) 53: 813-826

Proteomics analysis of regenerating amphibian limbs: changes during the onset of regeneration

Michael W. King, Anton W. Neff and Anthony L. Mescher

Int. J. Dev. Biol. (2009) 53: 955-969

5 yr ISI Impact Factor $(2013)=2.879$
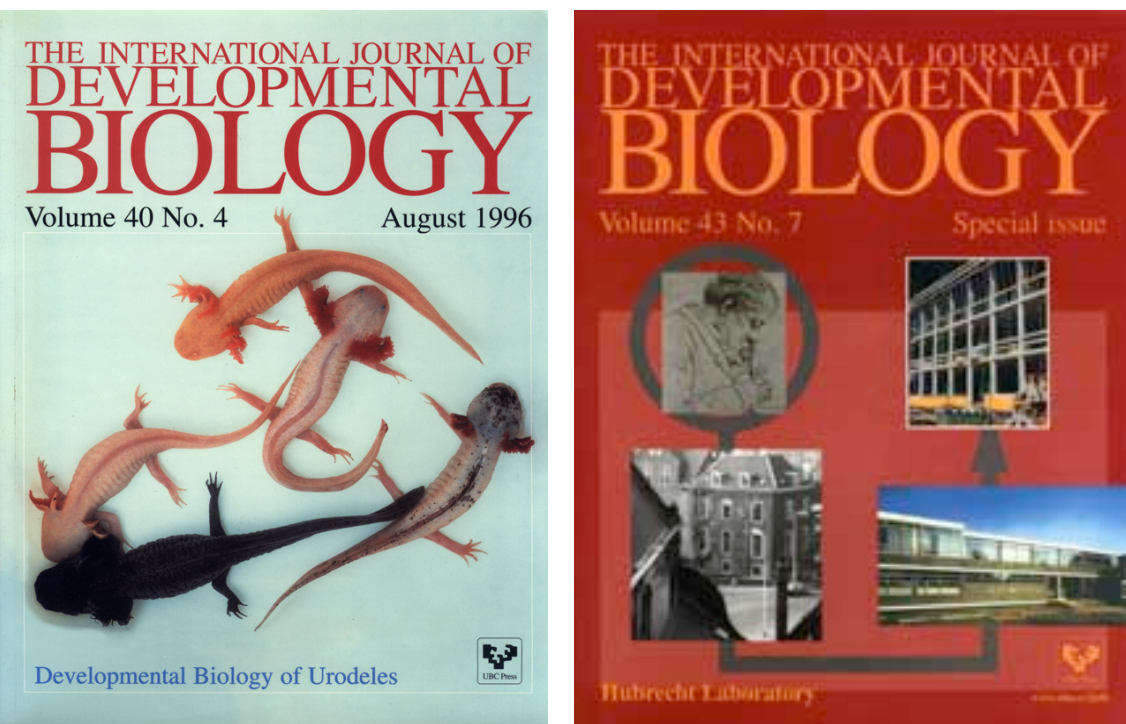
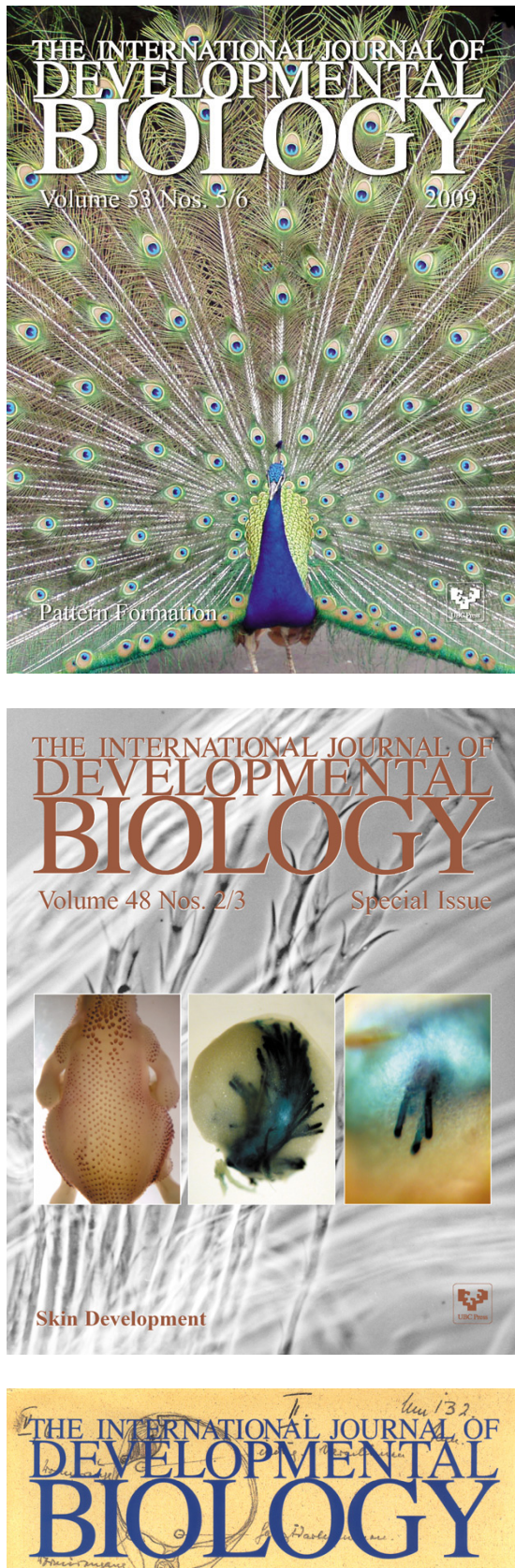

Volume 45 NO. 1
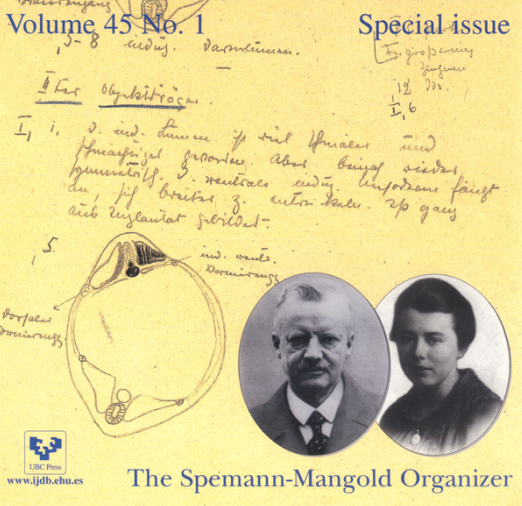